\title{
Ekajuk Language
}

National Cancer Institute

\section{Source}

National Cancer Institute. Ekajuk Language. NCI Thesaurus. Code C153908.

An Ekoid language of the Niger-Congo family spoken in the Cross River State and some surrounding regions of Nigeria. 